Research Article

\title{
Post Disaster Agricultural Strategies for Food Sufficiency and Economic Resilience: Special Focus on Gorkha, Nepal in Relation to Barpak Earthquake, 2015 Suroj Pokhrel ${ }^{\mathrm{a}^{*}}$
}

a. Former Secretary, Ministry of Land Management, Agriculture and Cooperative

Manuscript Received: January $242021 \quad$ Final Revision: August 17, $2021 \quad$ Accepted: September 6, 2021

\begin{abstract}
Barpak earthquake 2015 (7.8 Richter scale) killed 8,800 people, injured thousands and made nearly 3.5 million homeless. It created food shortage and hardship on livelihood because of damaged agricultural infrastructures, loss of stored food, feed, seed, livestock and reduced crop yield. This research aims to find out post the disaster situation of food availability, consumption and food balance in Gorkha district, as well as to assure livelihoods support and economic resilience. Relevant literature was reviewed, and field verification and interactions were organized in different rural municipalities/municipalities in the year 2019. The study revealed that Gorkha has a high agricultural potential with a surplus production of cereals $(49.7 \%)$, fruits $(6.2 \%)$ and spices $(175.7 \%)$. However, the surplus on cereals was only in Palungtar, Ajirkot, Arughat, Siranchok, Barpak Sulikot, Dharche and Gorkha municipalities (7491.3, 6000.1, 5946.6, 3424.9, 2699.8, 1255.2 and 707.3 t/year, respectively), but Chun Numbri, Bhimsen, Gandaki and Sahid Lakhan municipalities were in a deficit of 101, 661, 333 and 1799 t/year respectively. Moreover, the district was producing a negligible amount of fish, oilseed, ghee (animal) and honey but was in deficit in the production of vegetables $(31.5 \%)$, potato $(30.0 \%)$, milk $(29.6 \%)$, egg $(65.0 \%)$, meat $(54.0 \%)$ and pulses $(53.0 \%)$. In fact, the food surplus and deficit in different commodities varied in different municipalities with different degrees. It is thus suggested to adopt a municipality-wise, commercial-focused agriculture programme that includes potato/seed production in Chun Numbri (high hill), medicinal herbs in Dharche, maize in Barpak Sulikot, intercropping agroforestry of utis (Alnus nepalensis), timur (Zanthoxylum armatum), white sandalwood (Santalum album) with cardamom/tea/ coffee in Ajirkot, goat production in Siranchok and Arughat, avocado in Bhimsen, citrus in Sahid Lakhan, organic vegetables in Gandaki and Gorkha and milk/fruit production in Palungtar. Finally, it is recommended to integrate all the development programmes, farmers' welfare programmes, agro-tourism and resources to give synergy on food security and economic resilience of the earthquake victims in Gorkha district.
\end{abstract}

Keywords: earthquake, food deficit, livelihood, priority crop, resilience

* Corresponding author; E-mail: surojpokhrel@yahoo.com, CAuthor(s)

Published by Nepal Public Policy Review and peer-review under responsibility of Policy Research Institute Nepal. Licensed under CREATIVE-COMMONS license CC-BY-NC 4.0

(c) (i) (S) 


\section{Background}

Nepal is highly vulnerable to several disasters: earthquakes, floods, landslides, fires, epidemics, avalanches, windstorms, hailstorms, lightning, glacier lake outburst floods, droughts and dangerous weather events (Subedi and Poudyal Chhetri, 2019). Nepal falls under a seismic zone with the probability of large earthquakes of magnitude greater than seven in each 70-80 years (Mahato, 2014). It was placed at the eleven-top earthquake vulnerable countries in the world paralleled as sitting on a time-bomb. It has encountered 19 major earthquakes since the twelfth century (Subedi and Poudyal Chhetri, 2019). Earthquake is the scariest and the most damaging disaster in Nepal (Subedi and Poudyal Chhetri, 2019). Records show that since 1255 AD Nepal experienced 19 earthquakes with significantly large impacts. The last two big earthquakes that hit Nepal were that of 1833 (of 7.7 magnitude which killed 414 people) and 1934 (of 8.3 magnitude, 8519 people were killed). The other earthquakes that occurred in far western Nepal in 1980 (of 6.5 magnitude, 103 people were killed), and in eastern Nepal in 1988 (of 6.5 magnitude that killed 721 people) were comparatively much smaller in magnitude (Chhetri, 2018; Upreti, 2015).

There was a devastating earthquake of 7.8 magnitude on the Richter scale on 25 April 2015. Its epicentre was Barpak of Gorkha district. This earthquake severely affected 14 districts (Gorkha, Dhading, Rasuwa, Nuwakot, Kathmandu, Lalitpur, Bhaktapur, Kavrepalanchowk, Sindhupalchowk, Dolakha, Sindhuli, Makawanpur, Ramechhap and Okhaldhunga) and another 31 districts affected to varying extents (Chhetri, 2018; Upreti, 2015). The Gorkha earthquake enormously affected human, socio-economic and other multiple sectors and left deep scars mainly on the economy, livelihood and infrastructure of the country (Subedi and Poudyal Chhetri, 2019). The earthquakes destroyed 604,930 houses completely and 288,856 houses partially. It is estimated that the total value of the damages caused by the earthquakes was NPR 706 billion or equivalent to US\$ 7 billion (NPC, 2015).

Entire villages were flattened, especially those near the epicentre (Shrestha, 2015; McCarthy, 2015 and Kaini, 2015). The earthquake killed more than 8,800 people and injured nearly three times as many (Jason and Rauniyar, 2015). Likewise, nearly 3.5 million people became homeless (National Emergency Operation Centre, 2015). Around 800,000 people displaced by the earthquake in Nepal had to struggle to survive in a context of persistent and severe lack of safe and adequate housing, poor hygiene and trauma (AIN, 2015). Moreover, people did not receive recovery support immediately and had to spend the monsoon season without a house.

Reconstruction and recovery efforts have not been achieved as expected because of the weak governance and leadership of the National Reconstruction Authority (NRA). Humanitarian relief work, including immediate food support, remained chaotic for months until the rainy season. The majority of the people lacked food and shelter (Subedi and Poudyal Chhetri, 2019). The conflict victims who received supplies repeatedly complained that the rice distributed was "substandard and inedible" (Chhetri, 2018). Concerns were also expressed that crop harvests could be reduced or lost that season, as earthquake-affected people would have only a short time to plant crops before the onset of the monsoon (UNNC, 2015). Thousands of agricultural infrastructures, livestock/poultry shades, irrigation channels and storage were destroyed. Thousands of productive livestock were killed. A big volume of stored food, feed and seed was damaged, affecting food shortages and creating a hardship on the livelihood of the earthquake victims.

\section{Page $\mid 110$}


Gorkha is a geographically diverse district, politically divided into 11 rural municipalities/ municipalities in Gandaki province. The climate ranges from a southern tropical belt (3001,000 masl) to the subtropical, temperate, alpine and Himalayan belt (3,000 to 6,400 masl) in the north. Gorkha district covers an area of $3,610 \mathrm{~km}(1,390 \mathrm{sq} \mathrm{mi})$ and has a population of 271,061. Of these, Khas is the largest ethnic group (38\%) followed by Pahadi Brahmin (21\%) and Gurungs 16\%. Magar, Tamang, Ghale, Muslim, Newar, Kumal, Chepang, and Dalits are other ethnic and caste groups in the district (National Population and Housing Census, 2011). The population in northern rural municipalities is sparsely distributed. It is dense in the southern part of the district.

Chun Numbri, Dharche, Parpak Sulikot and Ajirkot rural municipalities lie in the north, Siranchok, Gorkha and Palungtar in the south-west and Arughat, Bhimsen, Sahid Lakhan and Gandaki in the south-east areas (Fig. 1).

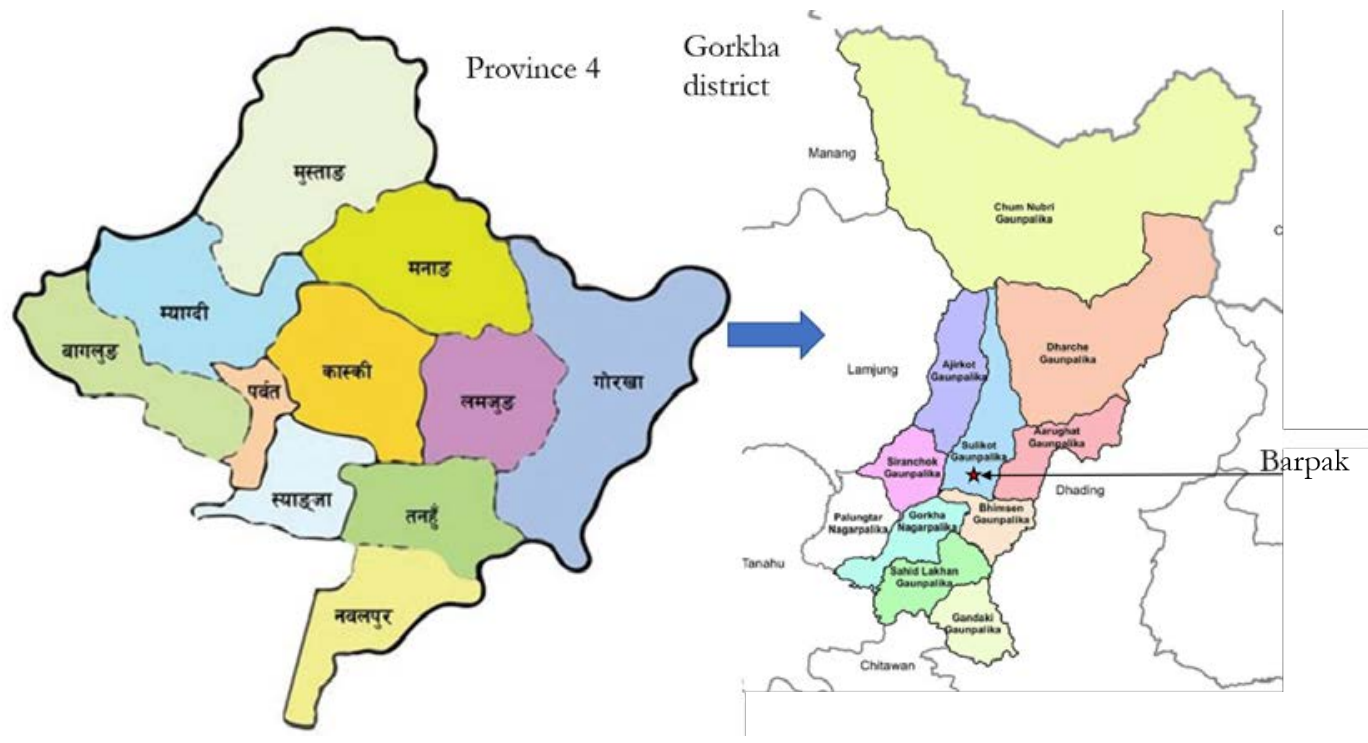

Fig. 1: Gandaki province, Gorkha district and municipalities, 2015.

\section{Problem statement/Rationale}

The post-disaster priority of the Nepal Reconstruction Authority (NRA) was on housing and infrastructure support rather than on food security, livelihood and economic resilience (NRA, 2016; Subedi and Poudyal Chhetri, 2019; Chhetri, 2018). A new project - Food and Nutrition Security Enhancement Project - was initiated to target the livelihood recovery and economic resilience of the earthquake-affected communities in eight different districts, including Gorkha (FAO, 2020). Although local, provincial and federal governments were involved in meeting the demand of the earthquake victims in the post-disaster period, all those efforts seemed insufficient for the livelihood recovery and economic resilience of the victims (Subedi and Poudyal Chhetri, 2019). Post-earthquake, food access in Gorkha district is decreasing because of low production, availability and low purchasing power, as well as poor food collection, distribution and marketing system (FAO, 2015a). Overall, the district appears to have a low 
level of investment in agriculture, donor-dependent food security programs, poor coordination, overlap and duplication among programs, the non-specified role of the private sector, insufficient marketing network and infrastructures and very low access of farmers' to government extension services (17\%) (Pokhrel, 2019).

In this situation, it is of utmost necessity to find the post-disaster food and nutrition availability and balance, and recommend the way forward for sustainable/commercial economic improvement of Gorkha district to ensure livelihood recovery and economic resilience for the earthquake victims.

\section{Literature review}

A natural disaster is a sudden event that causes widespread destruction, major collateral damage or loss of life, which might be earthquakes, flooding, volcanic eruption, landslide, hurricanes and so on. Nepal is prone to some of these types of natural disasters due to its geophysical structure, complex geology and climatic changes (Paudel Chhetri, 1999).

The biggest death toll by an earthquake in world history was in China (Shaanxi and Tangshan) which killed 830,000 and 655,000 people in 1556 and 1976 respectively, and the Haiti earthquake which killed 316,000 people in 2010 was the second-biggest (Deveci, 2018). A magnitude of 7.8 earthquake struck Nepal on April 25, 2015, and killed 9,000 people and injured 22,000 people. It was the deadliest earthquake in the seismically active region in 81 years (World Vision. 2018).

The Agricultural Livelihood Impact Appraisal (ALIA) undertaken by the Nepal Food Security Cluster, led by FAO in 2015, indicated the need for livelihoods support with the prioritized agricultural recovery programmes in more severely affected districts (6) including Gorkha. Impact on stored grains was very significant, particularly on rice, maize and millet seeds posing a threat to household food security. Destroyed agricultural tools have seriously reduced the capacity for cultivation. Household access to fertilizer and other inputs for use in the summer cropping season was reduced. Labour availability for agriculture was also a problem. Animal health was at risk due to a lack of shelter and feed. Animal losses were significant with $16 \%$ for cattle and $36 \%$ for poultry, with more animals injured and sick. Damage to small-scale irrigation had significant negative consequences on the winter cropping season. Limited technical services were available to farmers because of the damage to the Agricultural and Livestock Service Centre buildings and facilities (FAO, 2015b). The most urgent needs for the summer cropping season were seeds and fertilizers, followed by irrigation, tools and technical support. Rehabilitation of irrigation, as well as barley and wheat seeds, were the critical need for the winter cropping season. Recovery of the livestock shelter, support to feed and water access, restocking and health services were in urgent need. There was an urgent need to support and promote resilient livelihood recovery. However, the disaster management system, on the whole, was weak in Nepal.

Coordination across and within state agencies and government departments was equally poor. The recovery of the millions of people affected by the earthquake and the country to build back in a better, more resilient way is recommended by Risk Nexus (2014). Not only should there be a focus on the effects of this earthquake, there should also be a comprehensive approach to reduce the vulnerability of households to other more frequent hazards, such as

\section{\begin{tabular}{l|l} 
Page & 112
\end{tabular}}


landslides, floods, droughts, pests and diseases. The disaster-resilient agriculture that covers structural improvement of farm structures like storage houses, livestock and poultry shades, threshing floors, irrigation canals, pump houses and others, adoption of technologies that control soil erosion and conserve the soil carbon and moisture are equally important for earthquake resilience too. A diversified agriculture production system that includes an ecological design, adaption of traditional landscape technology and conservation agriculture is recommended (Lengnick, 2018). Improved institutional and technical capacities of farmer groups, adoption of improved agricultural technologies/practices, livestock, soil and plant health management, increased access of farmers to input and output market and improved rehabilitation work in agriculture infrastructures are important (ADRA, 2017). Particular awareness should be given to the needs of women farmers and elderly headed households (FAO, 2015b).

A proactive disaster management legislation focusing on disaster preparedness is important. Strong law enforcement and monitoring of building codes on earthquake-resistant construction practices are necessary. Adequate preparedness, response capacity and coordination among various stakeholders on disaster management are needed. Earthquake resistant infrastructures are needed. An arrangement should be made for appropriate and essential equipment/s and stuff - based on the nature of disaster - to undertake search and rescue works effectively. Modern technology and strategic communication/risk mapping/satellite mapping/earth observations are important tools and techniques to be applied in reducing disaster risks and life-saving (Subedi and Poudyal Chhetri, 2019). Mass awareness, community resilience, effective disaster governance, institutional efficiency in all phases (preparedness, response recovery and reconstruction) is necessary. The government, local people, INGOs, NGOs all should address disaster specific needs, priorities and plans to reduce risks and improve disaster management perspectives and skills (Chhetri, 2018). We must build on the fundamental strengths, social capital and community resilience that we possess. Educating the people to 'build back better' (BBB) must be the motto of the government. Non-governmental organizations, the private sector, experts, intellectuals, media and the international community can contribute to the rebuilding and disaster-preparation efforts by working together (Subedi and Poudyal Chhetri, 2019).

Earthquakes and any other disaster quickly create food shortages because of restrictions on transportation and disruptions in the markets (Patho.Org., 2019). Therefore, the establishment and management of an emergency supply chain during the containment effort is of paramount importance (Thomas et al., 2012). Agriculture and food security are among the sectors that get harshly affected by natural disasters by way of fluctuation in food production and disturbances in food trade and food supply chains (Reddy et al., 2016). Communication, food buffer stocking, safe transportation, supply and distribution during the period are paramount (The FIA, 2020). The Indian Council of Medical Research and the World Health Organization have per capita food recommendations for disaster-affected people for India and globally (ICMR, 1985, WHO, 1986). Nepal doesn't have such recommendations. ICMR recommendations can be taken as the reference for the calculation of food requirements in Nepal and Gorkha too (Table 1). 
Table 1:Per capita food recommendation, ICMR 1985

\begin{tabular}{|c|c|c|c|c|c|c|}
\hline \multirow{2}{*}{ Food group } & \multicolumn{3}{|c|}{ Daily(g/person/day) } & \multicolumn{3}{|c|}{ Yearly (kg/person/year) } \\
\hline & Minimum & Maximum & Average & Minimum & Maximum & Average \\
\hline Cereals & 400 & 650 & 525 & 146 & 219 & $\begin{array}{r}183 \\
(W H O, 1986)\end{array}$ \\
\hline Pulses & 55 & 80 & 67.5 & 20 & 32 & 26 \\
\hline $\begin{array}{l}\text { Green } \\
\text { vegetables }\end{array}$ & 100 & 125 & 112.5 & 37 & 46 & 41 \\
\hline $\begin{array}{l}\text { Tuber and } \\
\text { roots }\end{array}$ & 75 & 100 & 87.5 & 27 & 37 & 32 \\
\hline $\begin{array}{l}\text { Other } \\
\text { vegetables }\end{array}$ & 75 & 100 & 87.5 & 27 & 37 & 32 \\
\hline Fruits & 30 & 30 & 30 & 11 & 11 & 11 \\
\hline Milk & 100 & 200 & 150 & 37 & 73 & 55 \\
\hline Meat and fish & 30 & 30 & 30 & 11 & 11 & 11 \\
\hline Eggs & 30 & 30 & 30 & 11 & 11 & 11 \\
\hline $\begin{array}{l}\text { Sugar and } \\
\text { honey }\end{array}$ & 30 & 55 & 42.5 & 11 & 20 & 16 \\
\hline Fat and oils & 35 & 50 & 42.5 & 13 & 18 & 16 \\
\hline Total & 960 & 1450 & 1205 & 350 & 514 & 432 \\
\hline
\end{tabular}

Source: ICMR, 1985

Nepal has a lower rate of food self-sufficiency ratio (SSR) (FAO, 2003; Singh, 2008). This is very serious in northern Gorkha (AKC Gorkha, 2019). Hunger is mainly measured in terms of staples (Pariona, 2019). Although rice is the staple food in most of Gorkha, potato is considered a staple food in northern Gorkha. In addition, the food availability and balance are not uniform throughout the district. Northern Gorkha is most vulnerable to food insecurity (AKC Gorkha, 2019).

Each nation and municipality have their land and food policy and regulation in the world (Piesse, 2018) based on which they maintain food security. It is recommended to maintain at least a 50\% food deficit as buffer stocks for emergencies (Pokhrel, 2020a).

Countries like the US, China and Brazil, either have larger landmasses or are part of bigger economic unions to address the need for the expansion of cultivation areas and herd/farm sizes for commercial production (Piesse, 2018). However, in developing countries, commercialization is possible only with prioritized commodities with increased productivity potential and improved management practices (Pokhrel, 2020b) and other institutional services. Many other countries with the potential of good animal and crop yields, like the USA and India, have developed, popularized and scaled up high tech initiatives for high and quality yields (World Bank Group, 2020).

\section{Page| 114}


Food education is needed to improve a nutrition pattern and balanced diet in food consumption in Nepal (NeKSAP, 2012). Add, there is a need to replace the domination of supply-driven agriculture extension approaches with demand-driven services (Birner \& Anderson, 2007). Extension services based more on donor's interests than on the demand of farmers should be addressed (Dhital, 2017).

The cultivated area is 48,182 ha, of which $30.6 \%$ is irrigated. Besides crop production, livestock is another strong business in this district. The municipality-wise population, cultivated area (ha) and livestock population in the year 2019 were as below (Table 2):

Table 2: Population, cultivated area and livestock population in Gorkha, in 2019

\begin{tabular}{|c|c|c|c|c|c|c|c|c|c|c|c|}
\hline \multirow[b]{2}{*}{$\mathrm{SN}$} & \multirow{2}{*}{$\begin{array}{l}\text { Rural/ } \\
\text { Municipality }\end{array}$} & \multirow{2}{*}{$\begin{array}{l}\text { Popula- } \\
\text { tion }\end{array}$} & \multicolumn{3}{|c|}{ Cultivated area (ha) } & \multicolumn{6}{|c|}{ Livestock (Number) } \\
\hline & & & Irrigated & Rainfed & Total & Buffalo & Cattle & Goat & Sheep & $\begin{array}{r}\text { Chiken / } \\
\text { duck }\end{array}$ & Pigs \\
\hline 1 & Chun Numbri & 7417 & 130 & 1832 & 1702 & 10 & 1500 & 20250 & 10530 & 30245 & 150 \\
\hline 2 & Dharche & 13264 & 155 & 3099 & 3159 & 3450 & 7720 & 22580 & 10848 & 35570 & 580 \\
\hline 3 & B. Sulikot, & 25399 & 1635 & 3272 & 4907 & 1500 & 7150 & 20890 & 3662 & 45700 & 1500 \\
\hline 4 & Ajirkot & 15602 & 2176 & 1729 & 3905 & 8554 & 9856 & 24325 & 5240 & 48240 & 1000 \\
\hline 5 & Siranchok & 23666 & 1289 & 2071 & 3360 & 8988 & 9277 & 18347 & & 41300 & 2040 \\
\hline 6 & Arughat & 23915 & 735 & 7244 & 7979 & 8690 & 7633 & 17180 & & 42100 & 1840 \\
\hline 7 & Bhimsen & 22053 & 1229 & 1698 & 2972 & 9832 & 7634 & 16241 & & 40340 & 730 \\
\hline 8 & S.Lakhan & 27555 & 971 & 1733 & 2704 & 9834 & 9435 & 18603 & & 44380 & 1803 \\
\hline 9 & Gandaki & 23262 & 1012 & 1836 & 2848 & 7776 & 9497 & 18603 & & 43250 & 600 \\
\hline 10 & Gorkha & 50684 & 3242 & 2282 & 5524 & 5357 & 7322 & 15580 & & 42240 & 809 \\
\hline \multirow[t]{2}{*}{11} & Palungtar & 38244 & 2451 & 6537 & 8988 & 6681 & 7757 & 15870 & & 42580 & 710 \\
\hline & Total & $2,71,061$ & 14,744 & 33,438 & 48,182 & 69,672 & $84,781^{*}$ & $2,08,468$ & 30,280 & $4,56,245$ & 1,1762 \\
\hline
\end{tabular}

Note: Chauri $=4,630$

Source: AKC Gorkha, 2019; MoALD, 2019

\section{Research questions \& objectives}

The research questions on which the article builds were the following.

- Was the food supply/availability for the earthquake victims in different municipalities and rural municipalities in Gorkha sufficient during the post-disaster period?

- How the victims could recover their livelihood options for economic resilience through agriculture development in a sustainable way?

\section{Overall objective:}

The overall objective of the study was to explore options for "post-earthquake livelihood recovery and economic resilience of the earthquake victims in Gorkha district".

\section{Specific objectives:}

Specific objectives included the following:

- To identify the gaps in food and nutrition security of the post-earthquake situation in Gorkha district 
- To recommend appropriate agricultural strategies for different municipalities for the sustainable economic improvement of earthquake victims.

\section{Methodology}

\subsection{Literature review and data collection:}

Relevant literature from the journals, books, newsletters, web portals was reviewed. Secondary data on cultivated areas, livestock population, crop and animal production were collected from Agriculture Knowledge Centre (AKC), Gorkha and Ministry of Agriculture and Livestock Development (MoALD).

\subsection{Calculation of milling/dressing return of foods:}

The milling/dressing/processing returns of different commodities were calculated based on the following formula:

MRwt $(\%)=$ Gwt (100)- Bpwt $(\%)+$ Mls $(\%)$

Where, MRwt = weight of product after milling/processing or the milling return

$\mathrm{Gwt}=$ gross weight/production after harvesting

Bpwt $=$ weight of by product $/ \mathrm{s}$

Mls $=$ milling $/$ processing losses (wastage and moisture losses)

Example: Milling return of paddy (e-Krishi, 2020)

Where, Byproduct of rice (Bpwt) is husk (20\%), bran (5\%) and embryo $(3 \%)=28 \%$

Moisture and wastage loss $(\mathrm{Mls})=2 \%$

MRwt $(\%)=100-28+2=70 \%$

\subsection{Milling return of cereal and pulses}

Since the milling returns of maize and wheat are higher than paddy (97\%), the milling returns of cereals on average is considered to be $75 \%$. The milling return of pulses was found similar to cereals $(75 \%)$.

\subsection{Milling return of vegetables, spices and fruits}

The transportation loss of horticultural perishables like vegetables, spices and fruits was found very high (25-35\%) (Devkota et al., 2014). The moisture loss of potatoes in storage was about $4.78 \%$ and the weight losses measured up to $11 \%$ (Chourasia et al., 2005). In addition, potatoes are infested by various insect pests in storage in Nepal. Thus, the weight for table vegetables, fruits, spices and potatoes was estimated to be $75-85 \%$. The weight of processed tea/coffee was estimated to be $75 \%$, oil extraction from oilseed $38 \%$ and recovery of sugarcane $8 \%$ as per the standards. 


\subsection{Dressing return of livestock and poultry products}

The dressing return of meat is estimated to be $75 \%$, while, it is $72 \%$ for mutton, $80 \%$ for poultry and $75 \%$ for fish (Christopher, 1999). Since no significant processing loss is found with milk, egg, wool and honey, the recovery is calculated $100 \%$, while the milling return of tea and coffee is estimated at $75 \%$, oil $38 \%$ and sugar $8 \%$.

\subsection{Assessment of Food Self Sufficiency Ratio and Import Dependency Ration (IDR):}

The food self-sufficiency ratio (SSR) and the import dependency ratio (IDR) was calculated based on the following formula:

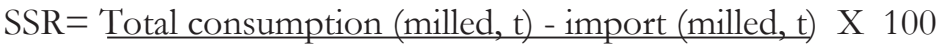

Total consumption (milled, $\mathrm{t}$ )

$\mathrm{IDR}=\mathrm{SSR}-100$

\subsection{Site Selection:}

Gorkha was selected for the study because of it being the epicentre of the Barpak earthquake, 2015. It represents all agroecosystems in high hills, mid-hills and foothills with river basins. All 9 rural municipalities and 2 municipalities (total 11) were taken for the study.

\subsection{Technical consultation:}

Technical checklists were prepared for each of the municipalities from a consultative meeting held in Nagarjun-1, Kathmandu on 16 March 2019. A total of 12 agricultural experts (horticulture 2, cardamom and coffee 1, apiculture 1, community development and social mobilization 1, agriculture extension 2, agri-economics 1, agronomy 1, fishery 1, soil conservation 1 and agroforestry 1) participated in the meeting. They were either from Gorkha or had the experience of work in the Gorkha district. The checklist was prepared to understand the possible agriculture commodities for commercial production and income generation in different agro-ecosystems in Gorkha.

\subsection{Field survey and Focused Group Discussion:}

Field visits and interactions with farmers were held along road/trail sites for easy access to information. Field visits to all municipalities were organized and verified in April 2019. Interactions were held among 10-15 key informant farmers and political leaders in a form of focus group discussion (FGD) in each municipality (total 140).

\subsection{Data analysis:}

Based on the production of commodities in the municipalities and the milling/dressing return, the SSR and IDR were calculated. Food requirement was assumed to be similar to the ICMR (?) 1985 recommendation. 
Feasible commodities, alternative and secondary agro-businesses for the particular geography were identified/segregated and tabulated based on the ranking of the commodities mentioned in the checklist. The lowest number was given to the most feasible commodity starting from 1-5 by the participants. The frequency was counted to find the most feasible commodity, followed by the alternative and secondary agro-businesses. Qualitative information collected from interactions and field visits were synthesized and, then, results were presented.

\section{Results and discussion}

Gorkha produces sufficient cereals, table fruits and spices (24631.6, 503.4 and 1429.1 t/year, respectively) to feed its population. However, the district was seriously deficient in the production of milled/processed pulses (3732.6 t), table vegetable (8533.9 t), potato/tubers (8119.6 t), meat (2047.4 t), fish (2955.7 t), eggs (8,453,900 pieces/year) and milk (7295.6 t/ year) in the year 2019 (Fig. 2, Table 3).

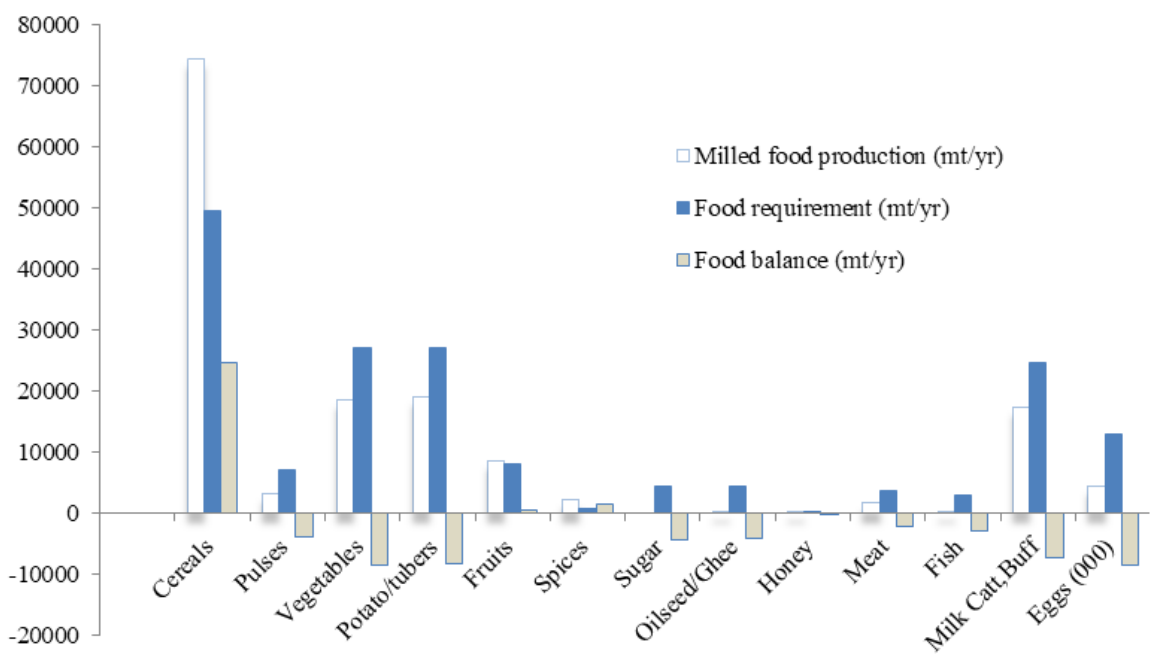

Fig.-2: Food production, requirement and balance in Gorkha, 2019

Table-3: Food/fiber production, requirement and balance in Gorkha district, 2019

\begin{tabular}{|c|c|c|c|c|c|c|c|c|c|}
\hline $\mathrm{SN}$ & $\begin{array}{l}\text { 害 } \\
\text { ठ } \\
\text { हू } \\
0\end{array}$ & 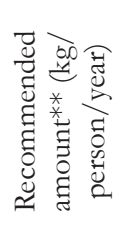 & 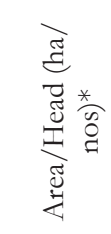 & 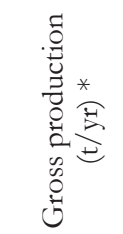 & 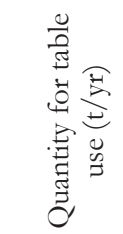 & 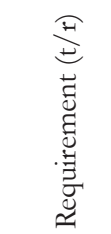 & 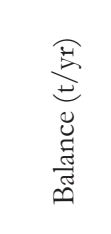 & $\begin{array}{l}\frac{\partial}{d} \\
\tilde{n} \\
\tilde{n}\end{array}$ & $\begin{array}{l}\frac{\mathfrak{d}}{a} \\
\frac{\mathfrak{a}}{\mathrm{a}}\end{array}$ \\
\hline 1 & Cereals & 183 & 48212 & 98981 & 74235.8 & 49604.2 & 24631.6 & 149.7 & 00 \\
\hline 2 & Pulses & 26 & 2310 & 4420 & 3315.0 & 7047.6 & -3732.6 & 47.0 & 53.0 \\
\hline 3 & Vegetables & 100 & 2456.5 & 24763 & 18572.3 & 27106.1 & -8533.9 & 68.5 & 31.5 \\
\hline 4 & $\begin{array}{l}\text { Potato/ } \\
\text { tubers }\end{array}$ & 100 & 2504 & 25315.4 & 18986.6 & 27106.1 & -8119.6 & 70.0 & 30.0 \\
\hline 5 & Fruits & 30 & 1437.5 & 11513.7 & 8635.3 & 8131.8 & 503.4 & 106.2 & 00 \\
\hline
\end{tabular}

Page| 118 
Suroj Pokbrel/Nepal Public Policy Review

\begin{tabular}{|c|c|c|c|c|c|c|c|c|c|}
\hline 6 & Spices & 3 & 382 & 2989.7 & 2242.3 & 813.2 & 1429.1 & 275.7 & 00 \\
\hline 7 & Sugar & 16 & 0 & 0 & 0.0 & 4337.0 & -4337.0 & 0.0 & 100.0 \\
\hline 8 & $\begin{array}{l}\text { Oilseed/ } \\
\text { Ghee }\end{array}$ & 16 & 865 & 856.5 & 325.5 & 4337.0 & -4011.5 & 7.5 & 92.5 \\
\hline 9 & Honey & 0.5 & 11609 & 9.85 & 9.9 & 135.5 & -125.7 & 7.3 & 92.7 \\
\hline 10 & Meat & 14 & - & 2330 & 1747.5 & 3794.9 & -2047.4 & 46.0 & 54.0 \\
\hline 11 & Fish & 11 & 17.38 & 34.6 & 26.0 & 2981.7 & -2955.7 & 0.9 & 99.1 \\
\hline 12 & $\begin{array}{l}\text { Milk } \\
\text { Catt,Buff }\end{array}$ & 91 & 154453 & 17371 & 17371 & 24666.6 & -7295.6 & 70.4 & 29.6 \\
\hline 13 & $\begin{array}{l}\text { Eggs(000 } \\
\text { nos) }\end{array}$ & 0.048 & 456245 & 4557 & 4557 & 13010.9 & -8453.9 & 35.0 & 65.0 \\
\hline
\end{tabular}

Note: Area coverage of tea and coffee in Gorkha was 2 and 20 ha and production was $1 \mathrm{t}$ and 84 t respectively $(0.8$ and $63 \mathrm{t}$ table tea and coffee). Sheep population was 30280 in 2018 producing 22.1t wool. Gorkha was deficient in tea, coffee and wool.

Source: *AKC Gorkha, 2019; MoALD, 2019. **ICMR, 1985

Gorkha does not produce sugar at all, and the production of consumable oil/fat (from oilseeds and milk) is also minimal. The deficit of sugar and oil/fat is about 4337.0 and $4011.5 \mathrm{~T} /$ year, respectively. There is an ample possibility to be self-sufficient in potato, vegetable and milk having a higher SSR (70.4, 70.0 and 68.5\%, respectively) (Fig. 1, Table 3).

The geographic diversity permits the possibility of commercialized production of different agricultural commodities in different municipalities for scaling up economic levels as following:

\subsection{Chun Numbri Rural Municipality}

Chun Numbri is the north most high-hill municipality in Gorkha connected to Tibet of China. The population of this rural municipality is 7,417. The gross and milled cereals and pulses production in Chun Numbri seems seriously deficit by 101.1 and $30.3 \mathrm{~T} /$ year, respectively. Fruits, sugar, oil/fat, fish, honey, milk and eggs are also in short supply. However, Chun Numbri is self-sufficient in meat, potato, vegetable and species (Table-4).

Production of high-hill potato and potato seeds seems most feasible in terms of livelihood recovery and economic resilience in Chum Numbri. Potato is a staple crop. Local black potato is unique in taste and colour. However, the inflow of improved varieties from outside the municipality is replacing the unique and valuable potato variety. Local potato seeds can be stored in room condition, it requires no cold storage. However, identification of geography and users group/s, training and capacity building, the establishment of facilities for true potato seed/pre-basic seed (TPS/PBS) production, construction of community storage and input management (seeds, irrigation, storage, organic manure, soft loan, technology, transportation, etc.) are necessary. The cultivation of medicinal herbs and development of production block/ pocket/cluster with neighbouring Dharche rural municipality could also be an alternative to potato cultivation. In addition, deciduous fruits, trout fish and ground apple production can be tied up with agro-tourism. The production of local black potato, which shall remain a staple crop, should be backed with further exploration of the market for tubers, seed potato and potato seeds, geographically indicated (GI) niche product and agro-tourism for livelihood recovery. Seed potato and potato products will have a high impact on income generation and economic resilience of earthquake victims in Chun Numbri. 
Table-4: Food/fiber production, requirement and balance in Chun Numbri, 2019

\begin{tabular}{|c|c|c|c|c|c|}
\hline SN & Commodity & $\begin{array}{r}\text { Gross production* } \\
(\mathrm{t} / \mathrm{yr})\end{array}$ & $\begin{array}{l}\text { Quantity for } \\
\text { table use ( } \mathrm{t} / \mathrm{yr})\end{array}$ & $\begin{array}{r}\text { Requirement } \\
(\mathrm{t} / \mathrm{yr})\end{array}$ & $\begin{array}{r}\text { Balance } \\
(\mathrm{t} / \mathrm{yr})\end{array}$ \\
\hline A & Sufficient & & & & \\
\hline 1 & Potato/tubers & 2639 & 1979.3 & 741.7 & 1237.6 \\
\hline 2 & Meat & 204 & 153.0 & 103.8 & 49.2 \\
\hline 3 & Spices & 59.5 & 44.6 & 22.3 & 22.3 \\
\hline 4 & Vegetables & 1012 & 759.0 & 741.7 & 17.3 \\
\hline B & Shortage & & & & \\
\hline 1 & Honey & 0 & 0.0 & 3.7 & -3.7 \\
\hline 2 & Eggs (000) & 302 & 302 & 356 & -54.0 \\
\hline 3 & Pulses & 216.6 & 162.5 & 192.8 & -30.3 \\
\hline 4 & Fish & 0 & 0.0 & 81.6 & -81.6 \\
\hline C & Acute shortage & & & & \\
\hline 1 & Cereals & 1675 & 1256.3 & 1357.3 & -101.1 \\
\hline 2 & Sugar & 0 & 0.0 & 118.7 & -118.7 \\
\hline 3 & Oilseed/Ghee & 0 & 0.0 & 118.7 & -118.7 \\
\hline 4 & $\begin{array}{l}\text { Milk } \\
\text { (Catt,Buff) }\end{array}$ & 172 & 172 & 674.9 & -502.9 \\
\hline 5 & Fruits & 103.2 & 77.4 & 222.5 & -145.1 \\
\hline $\mathrm{D}$ & Other & & & & \\
\hline 1 & Wool & 7.8 & 7.8 & NA & $\mathrm{NA}$ \\
\hline 2 & Lokta & 0.465 & 0.465 & NA & NA \\
\hline
\end{tabular}

*source: AKC Gorkha, 2019; MoALD, 2019.

\subsection{Dharche Rural Municipality}

Dharche is also a high-hill municipality in the Gorkha district. The population of Dharche is 13264 (Table-5). The gross and milled pulses, table vegetables and fruit production in Dharche are seriously in deficit by 231.7, 1128.4 and 339.4 t/year (Table-5). The municipality lacks sugar, oil/fat and fish production. However, Dharche is self-sufficient in cereals, potatoes, spices, meat and milk production.

Medicinal herbs production has already been initiated and is the most feasible and profitable enterprise in the municipality. Medicinal herbs are high-value saleable crops. Here too, harvested materials can be stored in room condition. For the commercialization of medicinal herbs, it needs to identify the geography and user group/s, training and capacity building, establishment of high tech facilities for the production of planting materials and medicinal herbs, construction of community storage house/s and input management (seeds/saplings, irrigation, storage, organic manure, soft loan, technology, transportation, etc.). Alternative activity can be high-hill potato/true potato seed production, and development of production block/pocket/cluster with Chun Numbri and Barpak Sulikot rural municipalities. Deciduous fruits, trout fish, ground apple, vegetables and vegetable seeds production could be tied up with agro-tourism, in addition to medicinal herbs, for the economic resilience of the earthquake victims. All these can sufficiently generate the employment and income of the people in Dharche municipality.

\section{Page 120}


Table-5: Food/fiber production, requirement and balance in Dharche, 2019

\begin{tabular}{llrrrr}
\hline SN & Commodity & $\begin{array}{r}\text { Gross Production } \\
(\mathrm{t} / \mathrm{yr})^{*}\end{array}$ & $\begin{array}{r}\text { Quantity for } \\
\text { table use }(\mathrm{t} / \mathrm{yr})\end{array}$ & $\begin{array}{r}\text { Requirement } \\
(\mathrm{t} / \mathrm{yr})\end{array}$ & $\begin{array}{r}\text { Balance } \\
(\mathrm{t} / \mathrm{yr})\end{array}$ \\
\hline A & Sufficient & 49105 & 3682.5 & 2427.3 & 1255.2 \\
1 & Cereals & 2022 & 1516.5 & 1326.4 & 190.1 \\
2 & Potato/tubers & 355 & 266.3 & 39.8 & 226.5 \\
3 & Spices & 361.5 & 271.1 & 185.7 & 85.4 \\
4 & Meat & 1284 & 1284 & 1207 & 77.0 \\
5 & Milk (Cattle/Buffalo) & & & & \\
$\mathrm{B}$ & Shortage & 0 & 0.0 & 6.6 & -6.6 \\
1 & Honey & 0 & 0.0 & 145.9 & -145.9 \\
2 & Fish & 151 & 113.3 & 344.9 & -231.7 \\
3 & Pulses & 355 & 355 & 636.7 & -281.7 \\
4 & Eggs (000) & & & 1326.4 & -1128.4 \\
$\mathrm{C}$ & Acute shortage & 264 & 198.0 & 212.2 & -212.2 \\
1 & Vegetables & 0 & 0.0 & 212.2 & -212.2 \\
2 & Sugar & 0 & 0.0 & 397.9 & -339.4 \\
3 & Oilseed/Ghee & 78 & 58.5 & & \\
4 & Fruits & & & $\mathrm{NA}$ & $\mathrm{NA}$ \\
$\mathrm{D}$ & Other & 7 & 7 & $\mathrm{NA}$ & $\mathrm{NA}$ \\
1 & Wool & 0.54 & 0.54 & & \\
2 & Lokta & & & & \\
\hline
\end{tabular}

*source: AKC Gorkha, 2019; MoALD, 2019.

\subsection{Barpak Sulikot Rural Municipality}

Barpak Sulikot is also a high-hill municipality in Gorkha. It was the epicentre of Barpak earthquake, 2015. The population of this rural municipality is 25399. Pulses, table vegetable, potato and fruit production in Barpak Sulikot are in serious deficit by 543.4, 1071.4, 2085.0 and $524.1 \mathrm{t} /$ year respectively (Table 6). Meat, milk, oil/fat and eggs are also in deficit in a considerable volume. Sugar is not produced in this municipality. However, Barpak Sulikot is self-sufficient in cereals and spices production (Table-6).

Hill maize seed/grain production is very suitable in Barpak Sulikot for commercialization, livelihood recovery and economic resilience. The demand for maize seed in the mid-hill is increasing rapidly. Maize grains can be used both for food and feed purposes. Barpak Sulikot is recently connected by a proper road. The main pre-requisites for the recovery of the municipality are commercialization of hill maize seed/grain production, identification of geography and user group/s, training and capacity building on production and post-harvest operations, the establishment of maize grit and feed industries, construction of community seed storage house/s with seed processing facility, and packing and input management (seeds, irrigation, storage, organic manure, soft loan, technology, transportation, etc.). Additionally, in Dharche and Chun Numbri municipality high hill potato tuber/seed production should be promoted. The probability of the production of white sandalwood (S. album) and timur (Z. armatum) cultivation, Apis cerana beekeeping and kiwi production should also be explored 
together with agro-tourism to enhance local food and nutrition security, employment and income generation and other supportive programs.

Table-6: Food/fiber production, requirement and balance in Barpak Sulikot, 2019

\begin{tabular}{|c|c|c|c|c|c|}
\hline $\mathrm{SN}$ & Commodity & $\begin{array}{r}\text { Gross } \\
\text { production } \\
(\mathrm{t} / \mathrm{yr}) * \\
\end{array}$ & $\begin{array}{r}\text { Quantity for table } \\
\text { use (t/yr) }\end{array}$ & $\begin{array}{r}\text { Requirement } \\
(\mathrm{t} / \mathrm{yr})\end{array}$ & $\begin{array}{r}\text { Balance } \\
(\mathrm{t} / \mathrm{yr})\end{array}$ \\
\hline A & Sufficient & & & & \\
\hline 1 & Cereals & 9797 & 7347.8 & 4648 & 2699.8 \\
\hline 2 & Spices & 331.8 & 248.9 & 76.2 & 172.7 \\
\hline B & Shortage & & & & \\
\hline 1 & Honey & 0.6 & 0.5 & 12.7 & -12.3 \\
\hline 2 & Meat & 223 & 223 & 355.6 & -132.6 \\
\hline 3 & Eggs (000) & 457 & 457 & 1219.2 & -762.2 \\
\hline C & Acute Shortage & & & & \\
\hline 1 & Potato/tubers & 606.6 & 455.0 & 2539.9 & -2085.0 \\
\hline 2 & Milk (Catt,Buff ) & 986 & 986 & 2311.3 & -1325.3 \\
\hline 3 & Vegetables & 1958 & 1468.5 & 2539.9 & -1071.4 \\
\hline 4 & Pulses & 156 & 117.0 & 660.4 & -543.4 \\
\hline 5 & Fruits & 317.2 & 237.9 & 762 & -524.1 \\
\hline 6 & Sugar & 0 & 0.0 & 406.4 & -406.4 \\
\hline 7 & Oilseed/Ghee & 14.85 & 5.6 & 406.4 & -400.8 \\
\hline $\mathrm{D}$ & Other & & & & \\
\hline 1 & Tea & 0 & 0.0 & NA & NA \\
\hline 2 & Coffee & 6 & 4.5 & NA & NA \\
\hline 3 & Fish & NA & NA & 279.4 & NA \\
\hline 4 & Wool & 2.5 & 2.5 & NA & NA \\
\hline 5 & Lokta & 0.75 & 0.75 & NA & $\mathrm{NA}$ \\
\hline
\end{tabular}

*source: AKC Gorkha, 2019; MoALD, 2019.

\subsection{Ajirkot Rural Municipality}

Ajirkot is also a high-hill municipality in Gorkha located near the epicenter of Barpak earthquake, 2015. It is recently connected by road. The population of this rural municipality is 15,602. Ajirkot municipality is in serious deficit in vegetable, potato and fruit production by 603.2, 165.1 and $378.7 \mathrm{t} /$ year. Meat and eggs are also in deficit in this district. Ajirkot does not produce sugar and oilseed in a considerable volume. However, Ajirkot is self-sufficient in cereals, pulses, spices and milk production (Table-7).

Timur (Z. armatum), white sandalwood (S. album), utis (A. nepalensis) based agroforestry and the plantation crops like cardamom, tea and coffee are the most feasible commodities for commercial production in Ajirkot. The Chepe Khola watershed area of Ajirkot is already commercialized in terms of cardamom, tea and coffee production. The geographically indicated (GI) organic market of these plantation crops and the product of timur (Z. armatum) and white sandalwood (S. album) are sound with high value. Fodder and deciduous fruit crops are also highly feasible. However, identification of geography and user group/s, the

\section{Page 122}


establishment of a high-tech bio-safe tissue culture lab, nurseries and resource centres for quality sapling production of timur (Z. armatum), white sandal (S. album), utis (A. nepalensis), cardamom, tea, coffee, fodder and deciduous fruits, together with training and capacity building on production and post-harvest operations, establishment of drying, processing, packaging and storage units for cereal grains and other commodities, including cardamom, tea and coffee, and input management (saplings, irrigation, storage, organic manure, soft loan, technology, transportation, etc.) are very important to enhance the income of the people. Goat production, kiwi, deciduous fruits, trout production, etc., can be alternative activities to generate additional income and employment.

Table-7: Food/fiber production, requirement and balance in Ajirkot, 2019

\begin{tabular}{|c|c|c|c|c|c|}
\hline $\mathrm{SN}$ & Commodity & $\begin{array}{r}\text { Gross } \\
\text { production } \\
(\mathrm{t} / \mathrm{yr})^{*} \\
\end{array}$ & $\begin{array}{r}\text { Quantity for } \\
\text { table use (t/ } \\
\text { yr) }\end{array}$ & $\begin{array}{r}\text { Requirement } \\
(\mathrm{t} / \mathrm{yr})\end{array}$ & $\begin{array}{r}\text { Balance }(\mathrm{t} / \\
\mathrm{yr})\end{array}$ \\
\hline A & Sufficient & & & & \\
\hline 1 & Cereals & 11807 & 8855.3 & 2855.2 & 6000.1 \\
\hline 2 & Milk (Cattle/Buffalo) & 2098 & 2098 & 1419.8 & 678.2 \\
\hline 3 & Spices & 418.7 & 314.0 & 46.8 & 267.2 \\
\hline 4 & Pulses & 834 & 625.5 & 405.7 & 219.8 \\
\hline B & Shortage & & & & \\
\hline 1 & Honey & 3 & 2.3 & 7.8 & -5.6 \\
\hline 2 & Meat & 253 & 189.8 & 218.4 & -28.7 \\
\hline 3 & Potato/tubers & 1860.2 & 1395.2 & 1560.2 & -165.1 \\
\hline 4 & Eggs (000) & 482 & 482 & 748.9 & -266.9 \\
\hline $\mathrm{C}$ & Acute Shortage & & & & \\
\hline 1 & Sugar & 0 & 0.0 & 249.6 & -249.6 \\
\hline 2 & Oilseed/Ghee & 26.73 & 10.2 & 249.6 & -239.4 \\
\hline 3 & Fruits & 119.14 & 89.4 & 468.1 & -378.7 \\
\hline 4 & Vegetables & 1276 & 957.0 & 1560.2 & -603.2 \\
\hline $\mathrm{D}$ & Other & & & & \\
\hline 1 & Tea & 1 & 0.8 & NA & $\mathrm{NA}$ \\
\hline 2 & Coffee & 48 & 36.0 & NA & NA \\
\hline 3 & Fish & $\mathrm{NA}$ & NA & 171.6 & NA \\
\hline 4 & Wool & 2.8 & 2.8 & NA & $\mathrm{NA}$ \\
\hline 5 & Lokta & 0.1 & 0.1 & NA & NA \\
\hline
\end{tabular}

*source: AKC Gorkha, 2019; MoALD, 2019.

\subsection{Siranchok Rural Municipality}

Siranchok is a mid-hill rural municipality in southwest Gorkha near Barpak. Siranchok is connected by an all-weather blacktopped road. The population of this rural municipality is 23666. Siranchok municipality is in serious deficit in milled pulses, table vegetables, fruits and meat production by 430.8, 1891.9, 551.3 and 178.3t/year. Eggs are also in deficit by 723000 pieces/year. Siranchok does not produce sugar, and the production of oil/fat is minimal. In contrast, honey and milk production in the municipality is almost at the self-sufficient level. 
Siranchok is self-sufficient in cereals, potato and spices production $(3424.9,430.8$ \& $266.7 \mathrm{t} /$ year respectively) (Table-8).

Goat production is the most appropriate business in Siranchok. It has sufficient forest areas, agro-forestry products and fodder. Goat meat has a good market demand and is an importing commodity in Nepal as a whole. Dairy goat is another demanding business. For commercial goat production in Siranchok, it needs to identify geography and user group/s, establish high tech breeding centre/resource centre for quality breeding stock production, and establish fodder nurseries, fodder tree planting, forage seed production and pasture management. Training and capacity building on husbandry management, input management (goat shades, drinking water, feed, soft loan, technology, transportation, health care and veterinary services, etc.) and the establishment of an organic manure factory are also equally important. In addition, rice/rice seed (Daraudi-Bhusunde) production, cerana beekeeping, cardamom/tea/coffee, kiwi, hill maize/maize seed production with agro-tourism can earn an additional income. The expected output can enhance local food and nutrition security and contribute to employment and income generation.

Table-8: Food/fiber production, requirement and balance in Siranchok, 2019

\begin{tabular}{llrrrr}
\hline SN & Commodity & $\begin{array}{r}\text { Gross production } \\
(\mathrm{t} / \mathrm{yr}) *\end{array}$ & $\begin{array}{r}\text { Quantity for } \\
\text { table use }(\mathrm{t} / \mathrm{yr})\end{array}$ & $\begin{array}{r}\text { Requirement } \\
(\mathrm{t} / \mathrm{yr})\end{array}$ & $\begin{array}{r}\text { Balance } \\
(\mathrm{t} / \mathrm{yr})\end{array}$ \\
\hline A & Sufficient & & & & \\
1 & Cereals & 10341 & 7755.8 & 4330.9 & 3424.9 \\
2 & Spices & 450.3 & 337.7 & 71 & 266.7 \\
3 & Potato/tubers & 3285.8 & 2464.4 & 2366.6 & 97.8 \\
$\mathrm{~B}$ & Shortage & & & & \\
1 & Honey & 0.5 & 0.4 & 11.8 & -11.4 \\
2 & Milk (Cattle/Buffalo) & 2082 & 2082 & 2153.6 & -71.6 \\
3 & Meat & 204 & 153.0 & 331.3 & -178.3 \\
4 & Eggs (000) & 413 & 413 & 1136 & -723.0 \\
$\mathrm{C}$ & Acute shortage & & & \\
1 & Sugar & 0 & 0.0 & 378.7 & -378.7 \\
2 & Oilseed/Ghee & 49.5 & 18.8 & 378.7 & -359.9 \\
3 & Pulses & 246 & 184.5 & 615.3 & -430.8 \\
4 & Fruits & 211.54 & 158.7 & 710 & -551.3 \\
5 & Vegetables & 633 & 474.8 & 2366.6 & -1891.9 \\
$\mathrm{D}$ & Other & & & & \\
1 & Tea & 0.5 & 0.4 & $\mathrm{NA}$ & $\mathrm{NA}$ \\
2 & Coffee & 10 & 7.5 & $\mathrm{NA}$ & $\mathrm{NA}$ \\
3 & Fish & $\mathrm{NA}$ & $\mathrm{NA}$ & 260.3 & $\mathrm{NA}$ \\
4 & Wool & 1 & 1 & $\mathrm{NA}$ & $\mathrm{NA}$ \\
\hline
\end{tabular}

*source: AKC Gorkha, 2019; MoALD, 2019. 


\subsection{Arughat Rural Municipality}

Arughat is a mid-hill rural municipality in southeast Gorkha. It is connected with road transportation. The population of this rural municipality is 23915 . Arughat is in deficit in pulses, table vegetables, fruits meat and milk production (438.8, 2031.5, 576.5, 192.3 and 315.3 t/year). Eggs are also in deficit by 726900 pieces/year. Arughat does not produce sugar at all while oil/fat is produced in minimal quantity. However, Arughat is self-sufficient in cereals, potato and spices production (5946.6, 2158 and 194.9 t/year respectively) (Table-9).

Arughat is also highly feasible for commercial goat farming. As in Siranchok, sufficient forest areas, fodder availability and proximity to NARC-promoted farm and market accessibility are supportive to goat keeping in Arughat too. Arughat is well connected by road. However, for commercial goat production, identification of geography and user group/s, the establishment of high-tech breeding centre/resource centre for quality breeding stock production, the establishment of fodder nurseries, forage seed production, fodder tree planting and pasture management, need to be ensured. Training and capacity building on husbandry management, input management (goat shades, drinking water, feed, soft loan, technology, transportation, health care and veterinary services, etc.) and the establishment of an organic manure factory are also necessary. Hill maize seed production in a block/pocket/cluster with Barpak Sulikot can be the alternative activity to goat farming. Cardamom/coffee and organic vegetable production, together with agro-tourism, can also earn an additional income. All this can enhance local food and nutrition security, generate employment and income from goat kids, meat, milk, manure and got-dairy related tourism. Hill maize seed/grain, cardamom/coffee, organic vegetable production can also support agro-tourism, livelihood recovery and economic resilience of the earthquake victims.

Table-9: Food/fiber production, requirement and balance in Arughat, 2019

\begin{tabular}{llrrrr}
\hline SN & Commodity & $\begin{array}{r}\text { Gross } \begin{array}{r}\text { Production } \\
(\mathrm{t} / \mathrm{yr})\end{array} \\
\text { A }\end{array}$ Sufficient & $\begin{array}{r}\text { Quantity for table } \\
\text { use }(\mathrm{t} / \mathrm{yr})\end{array}$ & $\begin{array}{r}\text { Requirement } \\
(\mathrm{t} / \mathrm{yr})\end{array}$ & $\begin{array}{r}\text { Balance } \\
(\mathrm{t} / \mathrm{yr})\end{array}$ \\
1 & Cereals & 13764 & 10323 & 4376.4 & 5946.6 \\
2 & Potato/tubers & 6066 & 4549.5 & 2391.5 & 2158 \\
3 & Spices & 355.5 & 266.6 & 71.7 & 194.9 \\
$\mathrm{~B}$ & Shortage & & & & \\
1 & Honey & 0.25 & 0.2 & 12 & -11.8 \\
2 & Meat & 190 & 142.5 & 334.8 & -192.3 \\
3 & Milk (Cattle/Buffalo) & 1861 & 1861 & 2176.3 & -315.3 \\
4 & Eggs (000) & 421 & 421 & 1147.9 & -726.9 \\
$\mathrm{C}$ & Acute shortage & & & & \\
1 & Sugar & 0 & 0 & 382.6 & -382.6 \\
2 & Oilseed/Ghee & 24.75 & 183 & 382.6 & -373.2 \\
3 & Pulses & 244 & 141.0 & 717.5 & -438.8 \\
4 & Fruits & 187.95 & 360 & 2391.5 & -2031.5 \\
5 & Vegetables & 480 & & &
\end{tabular}




\begin{tabular}{llrrrr}
1 & Fish & NA & NA & 263.1 & NA \\
2 & Tea & 0 & 0 & NA & NA \\
3 & Coffee & 6 & 4.5 & NA & NA \\
4 & Wool & 1 & 1 & NA & NA \\
5 & Lokta & 0 & 0 & NA & NA \\
\hline
\end{tabular}

*source: AKC Gorkha, 2019; MoALD, 2019.

\subsection{Bhimsen Rural Municipality}

Bhimsen is a mid-hill rural municipality in southeast Gorkha, connected by a black-top, allweather road. The population of this rural municipality is 22053. Bhimsen is in a deficit of milled cereals, pulses, table potatoes, fruits, meat and milk production $(660.7,467.7,1902.0$, 603.2, 182.0 and 1126.8 t/year). Eggs are also in deficit by 6,55,500 pieces/year. Bhimsen does not produce sugar at all while oil/fat is produced in minimal quantity. However, Bhimsen is self-sufficient in table vegetable and spices production (228.5 and $70.1 \mathrm{t} /$ year respectively) (Table-10).

Avocado could be one of the major commodities for cultivation in Bhimsen rural municipality. IDR of fruits in Nepal is $88.1 \%$ (MoALD, 2018) and the market price of avocado currently is about NPR $400 / \mathrm{kg}$, and its demand is very high in cities. Avocado reserves high nutritional and health value. Bhimsen rural municipality holds about $59 \%$ of total cultivated areas, which is rain-fed and highly feasible for avocado cultivation. However, for its commercial production, Bhimsen needs to identify geography and user group/s, establish high tech nurseries/resource centres for quality, grafted sapling production, establish avocado orchards and enhance skills in nursery and orchard management. Commercialisation also requires improved post-harvest operation, input management (saplings, irrigation, manure, soft loan, technology, transportation, plant protection, etc.), the establishment of post-harvest centres with grading, packaging and processing facilities, market promotion and marketing of avocado saplings, fruits and fruit products. Agro-forestry with white sandal and coffee, goat production and cerana beekeeping with agro-tourism can be alternative activities for extra income generation. The program can enhance local food and nutrition security, generate employment and income from avocado production and avocado-linked tourism. White sandal, coffee, goat farming and A. cerana beekeeping also can generate an additional income and add to agro-tourism.

Table-10: Food/fiber production, requirement and balance in Bhimsen, 2019

\begin{tabular}{llrrrr}
\hline SN & Commodity & $\begin{array}{r}\text { Gross production } \\
(\mathrm{t} / \mathrm{yr})^{*}\end{array}$ & $\begin{array}{r}\text { Quantity for } \\
\text { table use }(\mathrm{t} / \mathrm{yr})\end{array}$ & $\begin{array}{r}\text { Requirement } \\
(\mathrm{t} / \mathrm{yr})\end{array}$ & $\begin{array}{r}\text { Balance } \\
(\mathrm{t} / \mathrm{yr})\end{array}$ \\
\hline A & Sufficient & & & & \\
1 & Vegetables & 3245 & 2433.75 & 2205.3 & 228.5 \\
2 & Spices & 181.7 & 136.275 & 66.2 & 70.1 \\
$\mathrm{~B}$ & Shortage & & & & \\
1 & Honey & 0.25 & 0.25 & 11 & -10.8 \\
2 & Meat & 169 & 126.75 & 308.7 & -182.0 \\
3 & Eggs $(000)$ & 403 & 403 & 1058.5 & -655.5
\end{tabular}


Suroj Pokbrel/Nepal Public Policy Review

\begin{tabular}{llrrrr} 
C & Acute shortage & & & & \\
1 & Oilseed/Ghee & 176.22 & 67.0 & 352.8 & -285.8 \\
2 & Sugar & 0 & 0 & 352.8 & -352.8 \\
3 & Pulses & 141 & 105.75 & 573.4 & -467.7 \\
4 & Fruits & 77.9 & 58.425 & 661.6 & -603.2 \\
5 & Cereals & 4500 & 3375 & 4035.7 & -660.7 \\
6 & Milk(Cattle/Buffalo) & 880 & 880 & 2006.8 & -1126.8 \\
7 & Potato/tubers & 404.4 & 303.3 & 2205.3 & -1902.0 \\
$\mathrm{D}$ & Other & & & \\
1 & Tea & 0 & 0 & $\mathrm{NA}$ & $\mathrm{NA}$ \\
2 & Coffee & 2 & 1.5 & $\mathrm{NA}$ & $\mathrm{NA}$ \\
3 & Fish & $\mathrm{NA}$ & $\mathrm{NA}$ & 242.6 & $\mathrm{NA}$ \\
\hline
\end{tabular}

*source: AKC Gorkha, 2019; MoALD, 2019.

\subsection{Sahid Lakhan Rural Municipality}

Sahid Lakhan is a mid-hill rural municipality in south-east Gorkha. It is well connected by road transportation. The population of this rural municipality is 27555. Sahid Lakhan is in a deficit of milled cereals, pulses, table vegetables and potato/tubers, meat and milk production (1798.9, 632.4, 226.1 and 2414.3, 232.8 and 310.5 t/year). Eggs are also in deficit by 878600 pieces/ year. Sugar production is nil in Sahid Lakhanrural municipality, likewise, the oilseed production and milk fat production is also minimal. However, Sahid Lakhan is self-sufficient in table fruit and spices production (479.4 and $41.7 \mathrm{t} /$ year respectively) (Table-11).

Sahid Lakhan is already declared as a citrus production zone under the Prime Minister Agriculture Modernization Project. The municipality is highly feasible for the commercialization of citrus fruits because of its suitable geography, soil and climate. IDR of fruits in Nepal is about $88.1 \%$ (MoALD, 2018) and lemon and oranges are the most demanded and importpotential fruits in Nepal.

Per capita consumption of fruits in Nepal is very low (17 vs $30 \mathrm{~kg} / \mathrm{yr}$ of ICMR recommendation). For the commercialization of citrus cultivation in Sahid Lakhan rural municipality, it needs to identify geography and user group/s, establish high tech nurseries/resource centres for quality sapling production (nucellar, grafted, tissue culture), establish citrus (lemon/orange) orchards (one family 10 lemon tree can be a slogan and target) and arrange intensive management training and capacity building on nursery and orchard management, post-harvest operation, input management (saplings, irrigation, manure, soft loan, technology, transportation, plant protection, etc.) and market promotion. Avocado production in a block/pocket/cluster, with Bhimsen rural municipality, can be an alternative activity, together with the integration of goat production and cerana beekeeping and agro-tourism to generate employment and income. These activities will enhance local food and nutrition security and contribute to livelihood recovery and economic resilience. 
Table-11: Food/fiber production, requirement and balance in Sahid Lakhan, 2019

\begin{tabular}{llrrrr}
\hline $\mathrm{SN}$ & Commodity & $\begin{array}{r}\text { Gross } \begin{array}{r}\text { production } \\
(\mathrm{t} / \mathrm{yr})^{*}\end{array} \\
\text { A table use }(\mathrm{t} / \mathrm{yr})\end{array}$ & $\begin{array}{r}\text { Requirement } \\
(\mathrm{t} / \mathrm{yr})\end{array}$ & $\begin{array}{r}\text { Balance } \\
(\mathrm{t} / \mathrm{yr})\end{array}$ \\
\hline $\mathrm{A}$ & Sufficient & 1741.44 & 1306.1 & 826.7 & 479.4 \\
1 & Fruits & 165.9 & 124.4 & 82.7 & 41.7 \\
2 & Spices & & & & \\
$\mathrm{B}$ & Shortage & 0.25 & 0.3 & 13.8 & -13.6 \\
1 & Honey & 3372.5 & 2529.4 & 2755.5 & -226.1 \\
2 & Vegetables & 204 & 153.0 & 385.8 & -232.8 \\
3 & Meat & 2197 & 2197 & 2507.5 & -310.5 \\
4 & Milk(Cattle/Buffalo) & 444 & 444 & 1322.6 & -878.6 \\
5 & Eggs (000) & & & \\
$\mathrm{C}$ & Acute shortage & 44.55 & 16.9 & 440.9 & -424.0 \\
1 & Oilseed/Ghee & 0 & 0.0 & 440.9 & -440.9 \\
2 & Sugar & 112 & 84.0 & 716.4 & -632.4 \\
3 & Pulses & 3243.8 & 5042.6 & -1798.9 \\
4 & Cereals & 332.5 & & 2755.5 & -2414.3 \\
5 & Potato/tubers & 455 & & & \\
$\mathrm{D}$ & Other & 0 & 0.0 & $\mathrm{NA}$ & $\mathrm{NA}$ \\
1 & Tea & 3 & $\mathrm{NA}$ & $\mathrm{NA}$ \\
2 & Coffee & $\mathrm{NA}$ & $\mathrm{NA}$ & 303.1 & $\mathrm{NA}$ \\
3 & Fish & & & & \\
\hline
\end{tabular}

*source: AKC Gorkha, 2019; MoALD, 2019.

\subsection{Gandaki Rural Municipality}

Gandaki is a mid-hill rural municipality in south-east Gorkha. The sites of Gandaki have road access to major cities of Nepal. The population of this rural municipality is 23,262. Gandaki is in deficit in milled cereals, pulses, table potato/tubers and meat production (332.9, 495.3, 695.7 and 181.7 t/year, respectively). Eggs are also in deficit by 683,600 pieces/year. Gandaki rural municipality does not produce sugar at all. Production of oilseeds and milk fat is also insufficient. However, Gandaki municipality is self-sufficient in table vegetables, fruits, spices and milk production (1099.4, 3325.1, 25.0 and 80.2 t/year, respectively) (Table-12).

Organic vegetable production is found to be most feasible for commercialization, livelihood recovery and economic resilience for the earthquake victims in the Gandaki rural municipality. IDR of vegetables in Nepal is about 34.1\% (MoALD, 2018) and is an important commodity toward self-sufficiency in the country. The demand for organic vegetables in urban areas is rapidly increasing. Organic vegetables can get premium value and that is feasible in Gandaki. Commercial production of organic vegetables requires identification of geography and user group/s, the establishment of high tech nurseries/resource centres for quality seedling and seed production, the establishment of high tech and ordinary organic vegetable production farms, training and capacity building on nursery and farm management, post-harvest operation, input management (seeds, irrigation, manure, soft loan, technology, transportation, plant protection, cold chain/storage, etc.), the establishment of post-harvest centres with grading, packaging and processing facilities, marketing and market promotion. Goat farming can be an alternative activity, together with milk production, citrus cultivation, cerana beekeeping and

\section{Page 128}


agro-tourism for additional income. All these efforts can enhance local food and nutrition security, generate employment and income from organic vegetables, goat, milk, citrus production and cerana beekeeping and tourism for livelihood recovery and economic resilience of the earthquake victims in Gandaki rural municipality.

Table-12: Food/fiber production, requirement and balance in Gandaki, 2019

\begin{tabular}{|c|c|c|c|c|c|}
\hline $\mathrm{SN}$ & Commodity & $\begin{array}{r}\text { Gross production } \\
(\mathrm{t} / \mathrm{yr})^{*}\end{array}$ & $\begin{array}{l}\text { Quantity for } \\
\text { table use }(t / y r)\end{array}$ & $\begin{array}{r}\text { Requirement } \\
(\mathrm{t} / \mathrm{yr})\end{array}$ & $\begin{array}{r}\text { Balance } \\
(t / y r)\end{array}$ \\
\hline A & Sufficient & & & & \\
\hline 1 & Fruits & 5364 & 4023.0 & 697.9 & 3325.1 \\
\hline 2 & Vegetables & 4567.5 & 3425.6 & 2326.2 & 1099.4 \\
\hline 3 & Milk (Cattle/Buffalo) & 2197 & 2197.0 & 2116.8 & 80.2 \\
\hline 4 & Spices & 126.4 & 94.8 & 69.8 & 25.0 \\
\hline B & Shortage & & & & \\
\hline 1 & Honey & 3.5 & 3.5 & 11.6 & -8.1 \\
\hline 2 & Meat & 192 & 144.0 & 325.7 & -181.7 \\
\hline 3 & Cereals & 5232 & 3924 & 4256.9 & -332.9 \\
\hline 4 & Eggs (000) & 433 & 433.0 & 1116.6 & -683.6 \\
\hline C & Acute shortage & & & & \\
\hline 1 & Oilseed/Ghee & 24.75 & 9.4 & 372.2 & -362.8 \\
\hline 2 & Sugar & 0 & 0 & 372.2 & -372.2 \\
\hline 3 & Pulses & 146 & 109.5 & 604.8 & -495.3 \\
\hline 4 & Potato/tubers & 2174 & 1630.5 & 2326.2 & -695.7 \\
\hline $\mathrm{D}$ & Other & & & & \\
\hline 1 & Tea & 0 & 0 & NA & NA \\
\hline 2 & Coffee & 3 & 2.3 & NA & NA \\
\hline 3 & Fish & $\mathrm{NA}$ & NA & 255.9 & $\mathrm{NA}$ \\
\hline 4 & Wool & 0 & 0 & NA & NA \\
\hline 5 & Lokta & 0 & 0 & NA & $\mathrm{NA}$ \\
\hline
\end{tabular}

*source: AKC Gorkha, 2019; MoALD, 2019.

\subsection{Gorkha Municipality}

Gorkha municipality is in the mid-hill of south-west Gorkha. The population of the municipality is 50684. The municipality is in deficit in all food items except cereals. It is seriously in deficit in milled pulses, table vegetables, potato/tubers, fruits, spices, sugar, oilseed/ ghee, honey, meat and milk (792.8, 2504.2, 3938.9, 391.8, 81, 810.9, 698.0, 24.3 and 586.6 t/ year respectively). Eggs are also in deficit by 2643.200 pieces/year. However, Gorkha is selfsufficient in milled cereal production (707.3 t/year) (Table-13).

Organic vegetable production is highly feasible for commercial business in Gorkha municipality. IDR of vegetables in Nepal is about 34.1\% (MoALD, 2018) and is an important commodity to attain self-sufficiency. The demand for organic vegetables in urban areas of Nepal is rapidly increasing and it has premium value. There is road accessibility in Gorkha municipality for vegetable transportation and input supply. Identification of geography and user group/s, the establishment of high tech nurseries/resource centre for quality seedling and seed production, 
the establishment of high tech and ordinary organic vegetable production farms, training and capacity building on nursery/farm management and post-harvest operation, input management (seeds, irrigation, manure, soft loan, technology, transportation, plant protection, cold chain, etc.), the establishment of post-harvest centre with collection, grading, packaging and processing facilities, and marketing and market promotion support will contribute to commercial production of organic vegetables. Alternatively, rice/rice seed (Daraudi basin) production in a block/pocket/cluster, with Siranchok, can also be another important commodity to be considered. Milk production in a block/pocket/cluster with Palungtar and fish production tied up with agro-tourism can contribute to additional income. All these efforts can help local communities enhance their local food and nutrition security, generate employment and build economic resilience of the victims in Gorkha municipality.

Table-13: Food/fiber production, requirement and balance in Gorkha, 2019

\begin{tabular}{|c|c|c|c|c|c|}
\hline $\mathrm{SN}$ & Commodity & $\begin{array}{r}\text { Gross production } \\
(\mathrm{t} / \mathrm{yr})^{*}\end{array}$ & $\begin{array}{r}\text { Quantity for } \\
\text { table use }(\mathrm{t} / \mathrm{yr})\end{array}$ & $\begin{array}{r}\text { Requirement } \\
(\mathrm{t} / \mathrm{yr})\end{array}$ & $\begin{array}{r}\text { Balance } \\
(\mathrm{t} / \mathrm{yr})\end{array}$ \\
\hline $\mathrm{A}$ & Sufficient & & & & \\
\hline 1 & Cereals & 13310 & 9982.5 & 9275.2 & 707.3 \\
\hline B & Shortage & & & & \\
\hline 1 & Honey & 1 & 1 & 25.3 & -24.3 \\
\hline 2 & Spices & 94.8 & 71.1 & 152.1 & -81 \\
\hline 3 & Fruits & 1505 & 1128.8 & 1520.5 & -391.8 \\
\hline C & Acute shortage & & & & \\
\hline 1 & Meat & 164 & 123 & 709.6 & -586.6 \\
\hline 2 & Oilseed/Ghee & 297 & 112.9 & 810.9 & -698.0 \\
\hline 3 & Pulses & 700 & 525.0 & 1317.8 & -792.8 \\
\hline 4 & Sugar & 0 & 0 & 810.9 & -810.9 \\
\hline 5 & Eggs (000) & 422 & 422 & 2432.8 & -2010.8 \\
\hline 6 & Vegetables & 3419 & 2564.3 & 5068.4 & -2504.2 \\
\hline 7 & Milk (Cattle/Buffalo) & 1969 & 1969 & 4612.2 & -2643.2 \\
\hline 8 & Potato/tubers & 1506 & 1129.5 & 5068.4 & -3938.9 \\
\hline $\mathrm{D}$ & Other & & & & \\
\hline 1 & Tea & 0 & 0 & NA & NA \\
\hline 2 & Coffee & 12 & 9 & NA & NA \\
\hline 3 & Fish & NA & NA & 557.5 & NA \\
\hline 4 & Wool & 0 & 0 & NA & NA \\
\hline 5 & Lokta & 0 & 0 & NA & NA \\
\hline
\end{tabular}

*source: AKC Gorkha, 2019; MoALD, 2019.

\subsection{Palungtar Municipality}

Palungtar is a mid-hill municipality located in southwest Gorkha. The municipality is connected by an all-season blacktop road. The population of this municipality is 38244 . Palungtar is in deficit in table vegetable, potato/tubers, spices, meat and milk production (422.4, 2876.4, 2.1, 410.9 and 1835.2 t/year respectively). Eggs are also in deficit by 1410700 pieces/year. Production of sugar in Palungtar is nil and oilseed and milk fat productions are also insufficient. 
However, Palungtar is self-sufficient in milled cereals, pulses and table fruits $(7491.3,10.7$ and $208.8 \mathrm{t}$ /year respectively) (Table-14).

Table-14: Food/fiber production, requirement and balance in Palungtar, 2019

\begin{tabular}{llrrrr}
\hline SN & Commodity & $\begin{array}{r}\text { Gross production } \\
(\mathrm{t} / \mathrm{yr})^{*}\end{array}$ & $\begin{array}{r}\text { Quantity for } \\
\text { table use }(\mathrm{t} / \mathrm{yr})\end{array}$ & $\begin{array}{r}\text { Requirement } \\
(\mathrm{t} / \mathrm{yr})\end{array}$ & $\begin{array}{r}\text { Balance } \\
(\mathrm{t} / \mathrm{yr})\end{array}$ \\
\hline $\mathrm{A}$ & Sufficient & & & \\
1 & Cereals & 19320 & 14490 & 6998.7 & 7491.3 \\
2 & Fruits & 1808.07 & 1356.0525 & 1147.3 & 208.8 \\
3 & Pulses & 1340 & 1005 & 994.3 & 10.7 \\
$\mathrm{~B}$ & Shortage & & & \\
1 & Spices & 150.1 & 112.575 & 114.7 & -2.1 \\
2 & Honey & 0.5 & 0.5 & 19.1 & -18.6 \\
3 & Meat & 166 & 124.5 & 535.4 & -410.9 \\
4 & Vegetables & 3402 & 3824.4 & -422.4 \\
C & Acute shortage & 4536 & & & \\
1 & Oilseed/Ghee & 198 & 75.2 & 611.9 & -536.7 \\
2 & Sugar & 0 & 0 & 611.9 & -611.9 \\
3 & Eggs (000) & 425 & 425 & 1835.7 & -1410.7 \\
4 & Milk (Catt,Buff $)$ & 1645 & 1645 & 3480.2 & -1835.2 \\
5 & Potato/tubers & 1264 & 948 & 3824.4 & -2876.4 \\
$\mathrm{D}$ & Other & & & & \\
1 & Tea & 0 & 0 & $\mathrm{NA}$ & $\mathrm{NA}$ \\
2 & Coffee & 6 & $\mathrm{NA}$ & $\mathrm{NA}$ \\
3 & Fish & $\mathrm{NA}$ & $\mathrm{NA}$ & 420.7 & $\mathrm{NA}$ \\
4 & Wool & 0 & $\mathrm{NA}$ & $\mathrm{NA}$ \\
5 & Lokta & 0 & $\mathrm{NA}$ & $\mathrm{NA}$ \\
\hline
\end{tabular}

*source: AKC Gorkha, 2019; MoALD, 2019.

Milk production was found to be the most feasible commodity for commercialization in Palungtar. IDR of Milk in Nepal is about 21.0\% (MoALD, 2018) and milk is an important commodity to be self-sufficient. The demand for milk in urban areas is increasing by $8 \% /$ year?. (his question mark). Commercial dairy farming requires identification of geography and user group/s, the establishment of high tech fodder nurseries/resource centres for quality fodder seedling and forage seed production and developing pasture. The establishment of high tech buffalo and cattle dairy production farms and management of training and capacity building on milk production and post-harvest operation is equally important for commercial dairy farming. Input (breeding stocks, drinking water, soft loan, technology, transportation) and husbandry management and veterinary services are other important components to be addressed. Infrastructures like milk chilling centres, cattle/buffalo sheds, buffalo wallows, the establishment of organic manure/vermicompost factories, buffalo fattening centres and slaughterhouses are also required for the value chain management. Diversification of milk products for local consumption and market promotion is necessary.

Additionally, litchi and dragon fruit cultivation and citrus production can also be promoted. All these activities should be tied up with agro-tourism. The sale of milk, organic vegetables, litchi, citrus and dragon fruits, goat meat, and the promotion of agro-tourism can enhance 
local food and nutrition security and generate local employment for livelihood recovery and economic resilience in Palungtar municipality.

The study found that food availability was not similar across the municipalities during the postearthquake period. Food exchange among municipalities was possible but not enough. Each municipality needs to have its own focussed programme for livelihood support, as indicated by FAO $\left(2015_{\text {b. })}\right.$ with prioritized agricultural recovery programmes in Gorkha. Supporting and promoting resilient livelihood recovery is urgent in Gorkha, as recommended by Risk Nexus (2014) in case of the Karnali flood in Nepal. Disaster-resilient agriculture that covers structural improvement in farm structures like storage houses, livestock and poultry shades, threshing floors, irrigation canals, pump houses, adoption of technologies that control soil erosion and conserve soil carbon and moisture are equally important for earthquake resilience. A diversified agriculture production system that includes an ecological design and adapts to traditional landscape technology and agricultural conservation practices is recommended for the postdisaster response (Lengnick, 2018). Improved institutional and technical capacities of farmer groups, adoption of improved agricultural technologies/practices, livestock, soil and plant health management, increased access of farmers to input and output market and improved rehabilitation work in agriculture infrastructures are important in the post-disaster period as recommended by ADRA (2017). Awareness among women farmers and elderly headed households is also recommended (FAO, 2015

\section{Conclusion and recommendation}

Despite the earthquake, Gorkha was in surplus/sufficient in cereals production (49.7\%), fruits $(6.2 \%)$ and spices $(175.7 \%)$. It was however in an acute shortage of sugar $(100 \%)$, fish $(99.1 \%)$, oilseed/ghee $(92.5 \%)$, honey $(92.7 \%)$, poultry eggs $(65.0 \%)$, meat $(54.0 \%)$, pulses $(53.0 \%)$, vegetables (31.5\%), potato/tubers $(30.0 \%)$ and cattle and buffalo milk (29.6\%). High hill municipalities (Chun Numbri and the northern part of Darche, Barpak Sulikot and Ajirkot) were self-sufficient in potatoes, spices, vegetables, livestock and meat. However, they were in an acute shortage of cereals and pulses because of lower production and inaccessibility.

Local food production has to be strengthened for self-sufficiency in those municipalities. Mid hills and river basins of foothills are self-sufficient in cereals and fruit production but need other products. Local food exchange systems should be enhanced among the municipalities. The local governments should ensure food security and zero hunger as envisaged by the Agriculture Development Strategy (ADS), 2014; National Agriculture Policy, 2061; AgriBusiness Promotion Policy, 2063 and the Right to Food and Food Sovereignty Act, 2018.

They need to strengthen the system of local food production or supply in times of acute shortages and emergencies. However, for economic resilience, each municipality needs to develop a commercial agricultural block/pocket/cluster of selected commodities for high scale production in cooperation with neighbouring municipalities, as indicated by ADS, 2014 and National Agriculture Policy, 2004. Doing this requires a clear-cut division of roles and responsibilities of different stakeholders and well-developed coordination and linkage mechanisms to ensure integrated mobilization of resources for food security, economic growth and prosperity of earthquake victims and other people. Promoting earthquake-resilient agriculture also requires the adoption of measures suggested in the Land Use Policy, 2012; National Agrobiodiversity Policy, 2007 and the Climate Change Policy, 2011.

\section{Page| 132}


Based on the findings and the conclusion, the following recommendations are made. These recommendations are aligned with the goal of Agriculture Development Strategy, 2014; National Agriculture Policy, 2004; Agri-Business Promotion Policy, 2006, Right to Food and Food Sovereignty Act, 2018; Land Use Policy, 2012; National Agrobiodiversity Policy, 2007 and the Climate Change Policy, 2011.

- Maintain an emergency buffer stock of pulses, sugar and oil/fats (of at least 25\% of annual needs) in Gorkha and keep a buffer stock of cereals (at least $50 \%$ of the need) for high hill rural municipalities.

- Establish collection centres for perishable products in each municipality. Gorkha and Palungtar municipalities should additionally develop cold chain/storage facilities.

- Elevate potato farming to commercial production in Chun Numbri and the northern part of Dharche and Barpak Sulikot. Agro-tourism should also be promoted in these areas based on medicinal herbs, deciduous fruits, trout fish, ground apple cultivation and livestock rearing.

- Initiate commercial maize seed production in Barpak Sulikot as well as in southern Dharche and northern Siranchok, together with goat production, agroforestry with white sandalwood (S. album) and timur ( $Z$. armatum), cerana beekeeping and kiwi cultivation.

- Develop a commercial agroforestry and agro-tourism belt in Ajirkot and northern Siranchok based on timur (Z. armatum), white sandal wood (S. album), utis (A. nepalensis), cardamom, tea, coffee and other possible products, such as kiwi, deciduous fruits and trout fish.

- Undertake commercial goat farming in Siranchok and Arughat. Also, explore the possibility of maize seed production in the mid-hills of these municipalities and paddy seed production in the Daraudi-Bhusunde basin.

- Promote Bhimsen and Sahid Lakhan rural municipalities as the fruit-growing belt. Avocado production is recommended in Bhimsen and citrus in Sahid Lakhan.

- Ensure that Gorkha municipality and Gandaki rural municipality are developed into organic vegetable farming sites.

- Promote commercial dairy farming in Palungtar municipality, together with the production of litchi, dragon fruit, rice and citrus.

- Institutionalise a backup system to support the initiatives recommended above. Such a system should include agricultural research, advisory services, infrastructural support for irrigation, collection centres, market centres, community warehouses, cold storage/ chain, chilling centres and so on, input supplies (fertilizers, manures and soil amendments, seeds, breeds, saplings, equipment and machinery, etc), farmers' welfare scheme (crop and livestock insurance, soft loan scheme, subsidy support, contributory pension scheme and so on), and regulation and support services (diagnosis/treatment, soil/seed/pesticide testing, field layout, entrepreneurship development and so on).

- Promote earthquake-resilient agriculture practices in a manner that improve farm 
structures and adopt conservation technologies with a diversified agriculture production system and ecological design.

Local governments and other actors have a significant role to play to realise the recommendations presented. Local governments should provide financial subsidies, soft loans and human resources. The AKC, veterinary hospitals, CBOs and NGO/INGOs should take care of service delivery and capacity building of farmers. Cooperatives and the private sector should be responsible for post-harvest operation and marketing. NARC should conduct agriculture research in the field, while the user groups should take the responsibility of overall operation.

\section{References}

ADRA (Adventist Development and Relief Agency International). (2017). Food Security Enhancement and Agricultural Resilience for the Earthquake Affected Rural Nepalese Farmers (FOSTER). Adventist Development and Relief Agency International. http:// adranepal.org/?p=1131

AIN (Amnesty International Nepal). (2015). Earthquake Recovery Must Safeguard Human Rights. https://www.amnestyusa.org/wp-content/uploads/2017/04/p4583_ report_-_nepal_report_on_earthquake_web.pdf_-_adobe_acrobat_pro.pdf

AKC (Agriculture Knowledge Centre) Gorkha. (2019). Annual report, 2075/076. Agriculture Knowledge Centre Gorkha.

Birner, R. and Anderson, J. (2007). How to make agriculture extension demand driven? The case of India's agriculture extension policy. Discussion paper 00729. Washing D.C. International Food Policy Research Institute.

Chhetri, M.B.P. (2018). Socio-economic impacts and lessons learned from the Gorkha, Nepal Earthquake 2015. Presented Paper at the IDMC 22-24 October. Gumushane, Turkey; 2018

Chourasia, M.K., Maji, P., Baskey, A. and Goswami, T.K. (2005). Estimation of moisture loss from cooling data of potatoes. Journal of Food Process Engineering. 28(4), 397-416

Christopher, R.R. (1999). The butcher kept your meat? https://animalscience.psu.edu/ extension/meat/pdf/The\%20Butcher\%20Stole\%20My\%20Meat.pdf

Deveci, M. (2018). 10 deadliest earthquakes in history. https://www.aa.com.tr/en/americas/10-deadliest-earthquakes-in-history/1078343

Devkota, A.R., Dhakal, D.D., Gautam, D.M and Dutta, J.P. (2014). Assessment of fruit and vegetable losses at major wholesale markets in Nepal. International Journal of Applied Sciences and Biotechnology. 2(4), 559-562

Dhital, P.R. (2017). Agricultural extension in Nepal: experiences and issue. Journal Of Advances In Agriculture, 7(3), 1071-1082. doi: 10.24297/jaa.v7i3.6287

FAO (Food and Agriculture Organization). (2003). The state of food insecurity in the world. http://www.fao.org/docrep/006/j0083e/j0083e00.htm

FAO (Food and Agriculture Organization). (2015a). Nepal Earthquake Response: Joint Assessment of Food Security, Livelihoods and Early Recovery. https://reliefweb. int/report/nepal/nepal-earthquake-response-joint-assessment-food-security-liveli- 
hoods-and-early-recovery

FAO (Food and Agriculture Organization). (2015b). Nepal Earthquake: Agricultural Livelihood Impact Appraisal in Six Most Affected Districts. http://www.fao.org/ emergencies/resources/documents/resources-detail/en/c/293041/

FAO (Food and Agriculture Organization). (2020). Technical Assistance to Food and Nutrition Security Enhancement Project (FANSEP). http://www.fao.org/documents/card/en/c/CA8352EN/

GoN (2018). The Right to Food and Food Sovereignty Act, 2075 (2018)

ICMR (Indian Council of Medical Research). (1985). Nutritional requirements in India. http:/ / www.fao.org/3/x0172e/x0172e02.htm

Jason, B. and Rauniyar, I. (2015). Nepal earthquake death toll exceeds 6,000 with thousands unaccounted for. The Guardian. https://www.theguardian.com/world/2015/may/01/ nepal-earthquake-death-toll-passes-6000-with-thousands-still-missing

Kaini, S. (2015). Great Earthquake wipes out Barpak. The Kathmandu Post. Available at: https://kathmandupost.com/miscellaneous/2015/04/30/great-earthquake-wipesout-barpak

Lengnick, L. (2018). Cultivating Climate Resilience on Farms and Ranches Introduction to Climate Resilience in Agriculture. Sustainable Agriculture Research and Education (SARE). https://www.sare.org/publications/climate-risk-management-and-resilience-onfarms-and-ranches/introduction-7/

Mahato, R. (2014). Kathmandu is hit by a major earthquake every 70 or 80 years and the last was in 1934. City Monitor. https:// citymonitor.ai/fabric/kathmandu-hit-major-earthquakeevery-70-or-80-years-and-last-was-1934-556

McCarthy, J. (2015). He carried his mom on his back for 5 hours en route to medical care. Montana Public Radio. https://www.mtpr.org/post/he-carried-his-mom-his-back-5-hours-enroute-medical-care

MoAC (Ministry of Agriculture and Cooperative). (2007). National Agro-biodiversity Policy, 2007.

MoAD (Ministry of Agriculture Development).(2004). National Agriculture Policy, 2061

MoAD (Ministry of Agriculture Development). (2006). Agri Business Promotion Policy, 2063

MOAD (Ministry of Agriculture Development). (2014). Agriculture Development Strategy, 2014.

MoALD (Ministry of Agriculture and Livestock Development). (2018). Statistical information on Nepalese agriculture 2017/018. Agri-Business Promotion and Statistics Division, Singha Durbar, Kathmandu, Nepal.

MoALD (Ministry of Agriculture and Livestock Development). (2019). Statistical information on Nepalese Agriculture 2018/019. Agri-Business Promotion and Statistics Division, Singha Durbar, Kathmandu, Nepal.

MoSTE (Ministry of Science Technology and Environment). (2011). Climate Change Policy, 2011.

National Population and Housing Census. (2011). Central Bureau of Statistics. Government of Nepal. 
NeKSAP (Nepal Food Security Monitoring System). (2012). Nepal food balance by districts. https://reliefweb.int/sites/reliefweb.int/files/resources/wfp246336.pdf

NPC (National Planning Commission). (2017). Nepal Earthquake 2015: Post Disaster Needs Assessment Volume A: key findings. https:/ / www.npc.gov.np/images/category/PDNA_ Volume_A.pdf

NRA (National Reconstruction Authority). (2016). Post Disaster Recovery Framework 2016-2020. https: / / reliefweb.int/sites/reliefweb.int/files/resources/PDRF\%20 Report_FINAL10May.pdf

Pariona, A. (2019). What are the world's most important staple foods?. World Atlas. https:/ /www. worldatlas.com/articles/most-important-staple-foods-in-the-world.html

Patho.Org. (2019). Food security in a pandemic. https://www.paho.org/disasters/dmdocuments/RespToolKit_14_Tool\%2007_FoodSecurityinaPandemic.pdf

Paudel Chhetri, M.B. (1999). An overview of disaster management in Nepal: Nepal country report. Asian Disaster Reduction Center. https:/ /www.adrc.asia/countryreport/NPL/ NPLeng99/Nepal99.pdf

Pokhrel, S. (2019). Kina dozer lagaunu parchha tarkari barima (in Nepali). Nayapatrika daily, 08 February, 2019. P1.

Pokhrel, S. (2020a). Krishima aatma nirvar hune dabab (in Nepali). Nayapatrika daily,13 April, 2020.P10. https://www.nayapatrikadaily.com/news-details/41105/2020-04-13

Pokhrel, S. (2020b). Impact of covid-19 lockdown on agriculture and developing strategies against it for sustained food production and supply: special focus to Nepal. Journal of Environment Sciences. 6(1), 1-11.

Reddy, V.R., Singh, S.K. and Anbumozhi, V. (2016). Food supply chain disruption due to natural disasters: entities, risks, and strategies for resilience. https:/ / www.eria.org/ERIADP-2016-18.pdf

Risk Nexus. (2014). Urgent case for recovery: what we can learn from the August Karnali River floods in Nepal. https:// reliefweb.int/sites/reliefweb.int/files/resources/risk-nexus-karnali-river-floods-nepal-july-2015.pdf

Shrestha, S. (2015). Langtang is gone. Nepali Times. https://archive.nepalitimes.com/article/ nation/langtang-destroyed-in-earthquake

Singh, S. (2008). Marketing channels and their implications for smallholder farmers in India. In: McCullough, E., Pingali, P. and Stamoulis, K. eds. The transformation of agri-food systems: globalization, supply chains and smallholder famers. Earthscan: London.

Subedi, S. and Poudyal Chhetri, M.B. (2019). Impacts of the 2015 Gorkha Earthquake: Lessons Learnt from Nepal. In Earthquakes-Impact, Community Vulnerability and Resilience. doi: 10.5772/intechopen.85322

Piesse, M. (2018). Hunger amid abundance: The Indian food security enigma. Future Direction International. https://www.futuredirections.org.au/wp-content/uploads/2019/03/ Hunger-Amid-Abundance-The-Indian-Food-Security-Enigma.pdf

The FIA (Food Industry Association). (2020). Corona virus and pandemic preparedness for the food industry. https://www.fmi.org/docs/default-source/food-safety/pandemic-plana ning-final_verison3-12-20-6.pdf

\section{Page 136}


The World Bank Group. (2020). Agriculture and Food. https://www.worldbank.org/en/topic/ agriculture/overview

Thomas, K.D., Pappis, C.P. and Rachaniotis, N. (2012). Epidemics control and logistics operations: a review. International Journal of Production Economics. 139(2):393-410

UNNC (United Nations News Centre). (2015). In Nepal, senior UN official warns 'clock is ticking' for earthquake relief efforts. https://news.un.org/en/story/2015/05/497712-nepal-senior-un-official-warns-clock-ticking-earthquake-relief-efforts

Upreti, B.N. (2015). Causes, Consequences and Future Earthquake Disaster in Nepal-insights from the 2015 Gorkha Earthquake. Zambia: Department of Geology; School of Mines, University of Zambia; 2015

WHO (World Health Organization). (1986). In Max Roser and Hannah Ritchie, 2018. Food per person. OurWorldinData. https:/ / ourworldindata.org/food-per-person

World Vision. (2018). Nepal earthquake: Facts, FAQs, and how to help. https://www.worldvision. org/disaster-relief-news-stories/2015-nepal-earthquake-facts

\section{About Authors}

Suroj Pokhrel holds a Ph.D. Degree in Entomology. During his 34 years of service to the Government of Nepal. Dr Pokhrel worked in different capacities including District Agriculture Development Officer, Program Director, National IPM Coordinator, Director General, Joint Secretary and retired as Secretary, Ministry of Agriculture. Dr. Pokhrel also worked as Lead Consultant in FAO as Agro-ecosystem Expert. Presently, Dr. Suroj is associated with Practical Action Consulting as a Team Leader. He has published hundreds of research articles in peerreviewed journals, three books and several review articles. 